\title{
Migratory Aortitis Associated with Granulocyte-colony-stimulating Factor
}

\author{
Tsuyoshi Shirai, Hiroka Komatsu, Hiroko Sato, Hiroshi Fujii, \\ Tomonori Ishii and Hideo Harigae
}

\begin{abstract}
:
We herein report a case of migratory aortitis after the administration of granulocyte-colony-stimulating factor (G-CSF) to a 65-year-old woman with a history of pancreatic cancer. She was being administered pegfilgrastim and developed aortitis around the aortic arch. Although it resolved within two weeks, she again developed aortitis around the descending aorta, presenting as migratory aortitis, after pegfilgrastim was resumed. We further experienced three additional cases of G-CSF-induced aortitis that also showed spontaneous resolution, suggesting no or short-term use of immunosuppression. Aortitis due to G-CSF can present as migratory aortitis, since aortitis can quickly resolve and inflammation can recur at a different location.
\end{abstract}

Key words: aortitis, chemotherapy, granulocyte-colony-stimulating factor, migratory aortitis

(Intern Med 59: 1559-1563, 2020)

(DOI: 10.2169/internalmedicine.4331-19)

\section{Introduction}

Aortitis is a disease that causes inflammation in the vascular walls of the aorta and its main branches with various inflammatory symptoms, such as a fever and pain (1). As aortitis progresses, it leads to serious pathological conditions, such as aortic aneurysms and dissection, and becomes life threatening. Therefore, the early detection and immediate treatment are important.

The most common causes of aortitis are the primary vasculitides that include large vessel vasculitis (LVV) [Takayasu arteritis (TAK) and giant cell arteritis (GCA)], Behçet's disease, and Cogan's disease (2). In addition, infection and drugs have also been reported to cause aortitis $(3,4)$. These etiologies are sometimes difficult to distinguish, and the detailed mechanisms that cause inflammation in the vascular wall are unknown.

Recently, the development of aortitis following the use of granulocyte-colony-stimulating factor (G-CSF) has been recognized (5). We experienced four cases of aortitis associated with the use of G-CSF.

We herein report a case of migratory aortitis, an unusual manifestation of aortitis, associated with the administration of G-CSF.

\section{Case Report}

A 65-year-old woman was referred to our rheumatology department for the evaluation of a fever accompanied by thickening of the aortic arch. Two years earlier, she had suffered from pancreatic cancer and undergone distal pancreatectomy. Since then, the patient had been treated with titanium silicate (TS-1). Two months prior to admission, a liver metastasis had been diagnosed in her left lateral hepatic lobe. A central venous (CV) port had been inserted 27 days prior to admission, and FOLFIRINOX (fluorouracil, levofolinate calcium, irinotecan hydrochloride hydrate, and oxaliplatin) therapy had been initiated 15 days prior to admission. To prevent myelosuppression, pegfilgrastim (a longacting G-CSF) had been administered 12 days prior to admission.

She experienced a fever $\left(37^{\circ} \mathrm{C}\right) 4$ days prior to admission to the general surgery department. Laboratory findings showed elevated inflammatory markers, such as C-reactive protein $(11.8 \mathrm{mg} / \mathrm{dL})$, so she was admitted to our hospital. Computed tomography (CT) revealed soft-tissue thickening around the aortic arch without aortic dissection (Fig. 1). It

Department of Hematology and Rheumatology, Tohoku University Graduate School of Medicine, Japan

Received: December 13, 2019; Accepted: January 30, 2020; Advance Publication by J-STAGE: March 19, 2020

Correspondence to Dr. Tsuyoshi Shirai, tsuyoshirajp@med.tohoku.ac.jp 


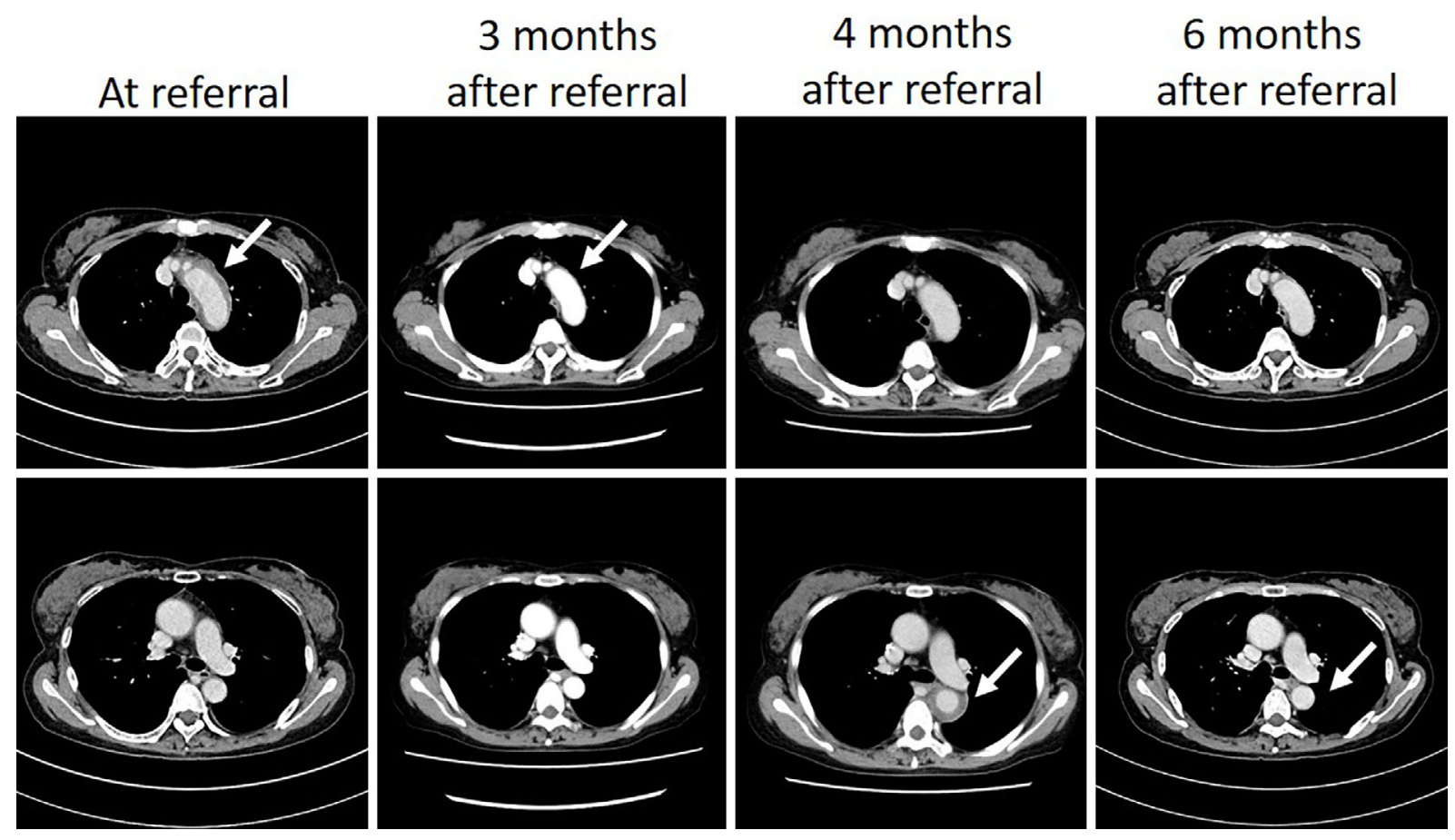

Figure 1. Thoracic aorta imaged by computed tomography. Findings at the time of referral and at months 3, 4, and 6 after referral are shown. White arrows indicate affected regions.

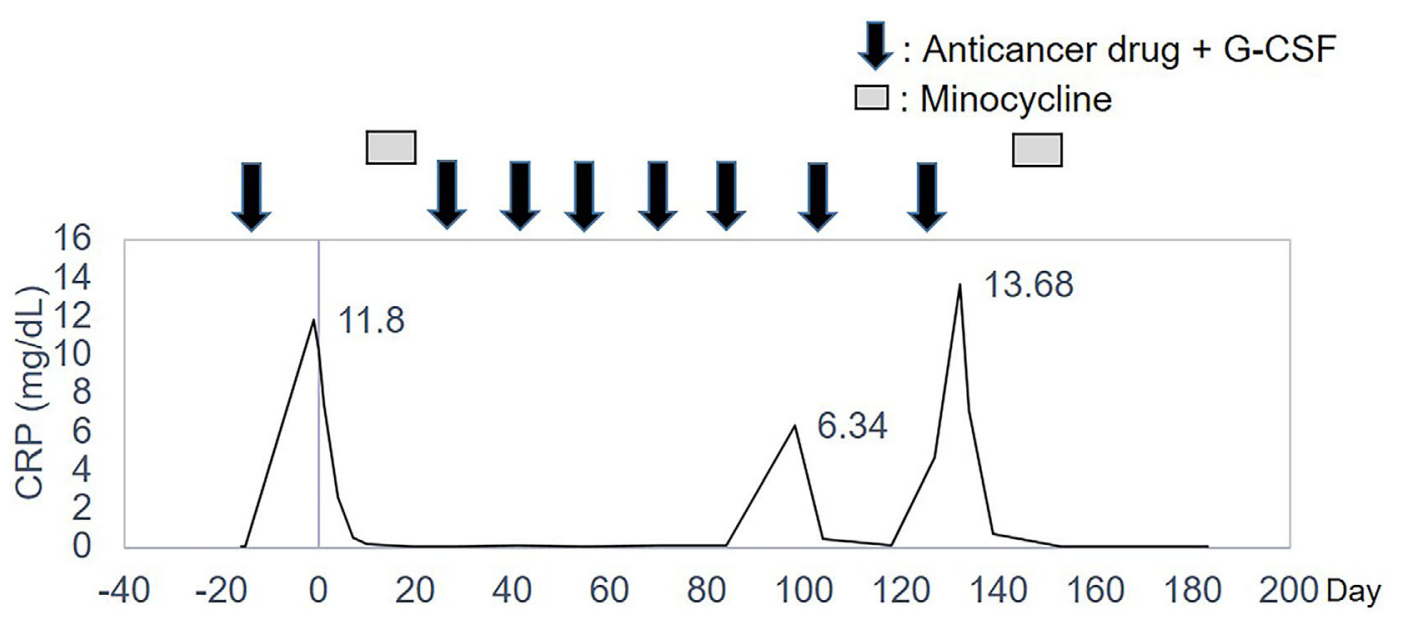

Figure 2. Clinical course. CRP: C-reactive protein, G-CSF: granulocyte-colony stimulating factor

was suspected that she was suffering from LVV, so she was referred to our department.

On referral, she had chest pain that corresponded to the position of the aortic arch. A physical examination revealed the following findings: blood pressure, 120/71 mmHg (without any difference between the upper limbs); pulse, 98 beats/min; body temperature, $39.1{ }^{\circ} \mathrm{C}$; and $98 \%$ oxygen saturation on room air. A cardiovascular examination revealed normal findings without bruits. Her lungs were clear during auscultation, and an abdominal examination was completely unremarkable with no skin lesions noted. Laboratory tests revealed an elevated erythrocyte sedimentation rate $(94 \mathrm{~mm} /$ h) and C-reactive protein (CRP) level (7.45 mg/dL, Fig. 2). The other findings were macrocytic anemia and hypoalbuminemia. Although her rheumatoid factor was slightly elevated
(20.8 IU/mL), tests for other autoantibodies were negative. The tumor marker CA19-9 was high $(92.0 \mathrm{U} / \mathrm{mL})$. Blood cultures and tests for syphilis and Chlamydia were negative.

Contrast-enhanced CT showed soft-tissue thickening with weak enhancement around the wall of the aortic arch (Fig. 1). Large-vessel magnetic resonance imaging (MRI) also confirmed wall enhancement of the affected lesion. These results indicated the presence of aortitis. Since the aortitis had occurred following the insertion of the $\mathrm{CV}$ port and chemotherapy, the differential diagnosis included infection, drug-induced inflammation, and primary LVV. Because the infectious etiology had not been ruled out, she was initially treated with minocycline. One week after the initiation of minocycline, marked improvement of the fever and inflammation were observed, and the patient's CRP levels 
had normalized. She was discharged on day 10, and CT showed improvement of the wall thickening (Fig. 1).

She received additional FOLFIRINOX treatments with pegfilgrastim, and occasionally manifested a fever and elevated CRP levels, both of which spontaneously resolved. Chemotherapy with pegfilgrastim was then restarted. Four months later, when she received her 7 th cycle of FOLFIRINOX therapy, she again complained of a high fever $\left(39^{\circ} \mathrm{C}\right)$, and her CRP levels were elevated at $13.68 \mathrm{mg} / \mathrm{dL}$ (Fig. 2). Using contrast-enhanced CT, soft-tissue thickening was found around the descending aorta without involvement of the aortic arch (Fig. 1). She was again referred to our department for an evaluation of aortitis. The affected artery lesions were migratory, which was an unusual manifestation of primary LVV. This, along with her medical history of spontaneous resolution of CRP levels during chemotherapy, which excluded an infectious etiology, prompted us to consider drug-induced aortitis.

Among the medications she had received, the complication of aortitis was documented only after the administration of pegfilgrastim. As continuing chemotherapy without pegfilgrastim was considered to pose a significant risk, partial hepatectomy was performed. Disappearance of the aortitis in the descending aorta was confirmed on follow-up CT (Fig. 1), and aortitis has not recurred in over one year.

We further experienced an additional three cases of aortitis associated with chemotherapy, with pegfilgrastim commonly used in all three (Table). In cases \#20 and \#21 in particular, aortitis developed when pegfilgrastim was administered for leukopenia, even though these patients had received the same chemotherapy regimen. This confirmed that a relationship thus exists between G-CSF and aortitis. In these three cases, the use of pegfilgrastim was discontinued, and aortitis has not recurred.

\section{Discussion}

In the present report, we described a case of migratory aortitis caused by the administration of G-CSF. Although the occurrence of aortitis following the use of G-CSF has been recognized increasingly frequently, the natural course of aortitis caused by G-CSF has not been well documented, as corticosteroids were used in previously reported cases. We further experienced three additional cases, which also showed spontaneous improvement. Although it was difficult to exclude the effects of anti-cancer drugs on the development of aortitis completely, the use of pegfilgrastim was common among these cases, indicating the critical role of G-CSF for the development of aortitis. The present cases provided the following evidence in G-CSF-induced aortitis: a spontaneous resolution was expected; aortitis did not occur every time following G-CSF administration; and the site of inflammation was migratory.

To gather data related to G-CSF-induced aortitis, we searched the PubMed database using the term "G-CSF and aortitis" (6). Seventeen case reports were found between
2004 and 2019 (5, 7-11). In addition to the previous reports, a total of 21 cases were summarized, including the present case and other cases from our department (Table). The median age was 65 years old, and 17 of the 21 cases occurred in women. The most common underlying cancers were uterine and breast ( 4 cases, each). In all cases, aortitis developed in a short period of time (within 15 days) after the administration of G-CSF. It is notable that many reports are from Japan, and pegfilgrastim was used in most of those cases. Although we were not able to identify the site of inflammation in some cases, the site of aortitis was located at the abdominal aorta in three cases and at the thoracic aorta in seven cases. Only 9 of the 21 cases were treated with steroids. Nevertheless, all cases improved without developing chronic aortitis, such as TAK (12). Since steroids were used in most of the cases reported, this is the first detailed report describing the natural course of aortitis induced by repeated G-CSF use. As in the present case, aortitis due to G-CSF use can be expected to improve when the effect of G-CSF disappears. This means that immunosuppressive therapy is not required in most cases. However, it should also be noted that intense acute inflammation can rarely cause fatal side effects, such as asymptomatic aortic dissection, as previously reported (11). Parodis et al. reviewed the contribution of corticosteroids and concluded that moderate-to-high doses of corticosteroids should be started immediately following the diagnosis (10). Since vascular inflammation can improve spontaneously, as shown in the present case, it is difficult to conclude that immunosuppressants should be initiated for the treatment of LVV. However, the short-term use of immunosuppressants may be an option, considering the risk of developing aortic dissection. Although we did not treat any cases with immunosuppressants, aortitis resolved spontaneously without complication.

In the present case, the continuation of chemotherapy took precedence, and the patient did not experience aortitis following four cycles of chemotherapy. However, the elevation of inflammatory markers was eventually observed in three of eight cycles of chemotherapy. This clinical course indicated that this adverse event was not merely due to an allergic reaction to the G-CSF. In the present case, CT showed an improvement in wall thickening around the aortic arch three months after referral. Interestingly, at the last event, a new lesion appeared in the descending aorta, which had been intact at the first event, providing an unusual finding of migratory aortitis. Anti-cancer drugs are thought to cause chemical inflammation due to vascular disorders, but G-CSF is thought to cause inflammation due to an autoimmune mechanism induced by neutrophils. The occurrence of Sweet syndrome and leukocytoclastic vasculitis due to GCSF has also been reported (13). Importantly, the incidence of aortitis was higher with pegfilgrastim, a long-acting form, than with filgrastim (Table). Although TAK and GCA are diseases affecting the aorta, vascular Behcet's disease, in which neutrophils play critical roles, also manifests aortitis. The serum G-CSF levels are reported to be elevated in the 
Table. The Clinical Characteristics of Patients with G-CSF-induced Aortitis.

\begin{tabular}{|c|c|c|c|c|c|c|c|c|c|c|c|}
\hline Case & Country & $\begin{array}{c}\text { Age } \\
\text { (years) }\end{array}$ & Sex & $\begin{array}{l}\text { Underlying } \\
\text { disease }\end{array}$ & G-CSF & $\begin{array}{l}\text { Time to } \\
\text { onset } \\
\text { aortitis }\end{array}$ & Cancer treatment & Aortitis & Treatment & $\begin{array}{c}\text { Outcome } \\
\text { following } \\
\text { discontinuation }\end{array}$ & Ref \\
\hline 1 & France & 55 & Female & None & Filgrastim & 6 days & $\mathrm{n} / \mathrm{a}$ & Abdominal & Steroid & $\begin{array}{l}\text { Resolved in } \\
6 \text { months }\end{array}$ & (7) \\
\hline 2 & Germany & Unknown & Male & $\begin{array}{c}\text { B cell } \\
\text { lymphoma }\end{array}$ & Pegfilgrastim & 15 days & Not reported & $\begin{array}{l}\text { Not } \\
\text { reported }\end{array}$ & $\begin{array}{l}\text { Not } \\
\text { reported }\end{array}$ & Resolved & (8) \\
\hline 3 & Japan & 49 & Female & $\begin{array}{l}\text { Uterine } \\
\text { cancer }\end{array}$ & Filgrastim & 6 days & Not reported & $\begin{array}{l}\text { Not } \\
\text { reported }\end{array}$ & NSAID & $\begin{array}{l}\text { Resolved in } \\
1 \text { months }\end{array}$ & (8) \\
\hline 4 & US & 54 & Male & $\begin{array}{l}\text { Lung } \\
\text { cancer }\end{array}$ & Filgrastim & 13 days & Carboplatin & Abdominal & Steroid & Resolved & (5) \\
\hline 5 & Israel & 52 & Male & $\mathrm{n} / \mathrm{a}$ & Filgrastim & $\begin{array}{c}6 \\
\text { months }\end{array}$ & $\mathrm{n} / \mathrm{a}$ & Abdominal & Steroid & Resolved & (9) \\
\hline 6 & Japan & 72 & Female & $\begin{array}{l}\text { Uterine } \\
\text { cancer, }\end{array}$ & Pegfilgrastim & 13 days & Not reported & $\begin{array}{l}\text { Not } \\
\text { reported }\end{array}$ & None & $\begin{array}{l}\text { Resolved in } \\
1.5 \text { months }\end{array}$ & (8) \\
\hline 7 & Japan & 76 & Female & $\begin{array}{l}\text { Breast } \\
\text { cancer }\end{array}$ & Pegfilgrastim & 7 days & Not reported & $\begin{array}{l}\text { Not } \\
\text { reported }\end{array}$ & None & $\begin{array}{l}\text { Resolved in } \\
11 \text { days }\end{array}$ & (8) \\
\hline 8 & Japan & 77 & Female & $\begin{array}{l}\text { Ovarian } \\
\text { cancer }\end{array}$ & Filgrastim & 7 days & Not reported & $\begin{array}{l}\text { Not } \\
\text { reported }\end{array}$ & None & $\begin{array}{l}\text { Resolved in } \\
1 \text { month }\end{array}$ & (8) \\
\hline 9 & Japan & 47 & Female & $\begin{array}{l}\text { Ovarian } \\
\text { cancer }\end{array}$ & Lenograstim & 8 days & Not reported & $\begin{array}{l}\text { Not } \\
\text { reported }\end{array}$ & Steroid & $\begin{array}{l}\text { Resolved in } \\
3 \text { months }\end{array}$ & (8) \\
\hline 10 & Japan & 61 & Female & $\begin{array}{l}\text { Breast } \\
\text { cancer }\end{array}$ & Pegfilgrastim & 7 days & Not reported & $\begin{array}{l}\text { Not } \\
\text { reported }\end{array}$ & None & $\begin{array}{l}\text { Resolved in } \\
26 \text { days }\end{array}$ & (8) \\
\hline 11 & Japan & 62 & Female & $\begin{array}{c}\text { B cell } \\
\text { lymphoma }\end{array}$ & Pegfilgrastim & 12 days & Not reported & $\begin{array}{l}\text { Not } \\
\text { reported }\end{array}$ & Steroid & Resolved & (8) \\
\hline 12 & Japan & 65 & Female & $\begin{array}{l}\text { Breast } \\
\text { cancer }\end{array}$ & Pegfilgrastim & 9 days & Not reported & $\begin{array}{l}\text { Not } \\
\text { reported }\end{array}$ & Steroid & $\begin{array}{l}\text { Resolved in } \\
1 \text { month }\end{array}$ & (8) \\
\hline 13 & Japan & 66 & Male & $\begin{array}{l}\text { Prostate } \\
\text { cancer }\end{array}$ & Pegfilgrastim & 8 days & Not reported & $\begin{array}{l}\text { Not } \\
\text { reported }\end{array}$ & None & $\begin{array}{l}\text { Resolved in } \\
1 \text { month }\end{array}$ & (8) \\
\hline 14 & Japan & 67 & Female & $\begin{array}{l}\text { Lung } \\
\text { cancer }\end{array}$ & Pegfilgrastim & 8 days & Not reported & Thoracic & Steroid & $\begin{array}{l}\text { Resolved with } \\
\text { dissection at } \\
\text { day } 36\end{array}$ & (11) \\
\hline 15 & Japan & 69 & Female & $\begin{array}{l}\text { Esophageal } \\
\text { cancer }\end{array}$ & Pegfilgrastim & 11 days & Not reported & $\begin{array}{l}\text { Not } \\
\text { reported }\end{array}$ & None & $\begin{array}{l}\text { Resolved in } \\
11 \text { days }\end{array}$ & (8) \\
\hline 16 & Sweden & 70 & Female & $\begin{array}{l}\text { Breast } \\
\text { cancer }\end{array}$ & Filgrastim & 9 days & $\begin{array}{l}\text { Docetaxel, } \\
\text { Trastuzumab, } \\
\text { Pertuzumab }\end{array}$ & Thoracic & Steroid & $\begin{array}{l}\text { Resolved in } \\
15 \text { days }\end{array}$ & (10) \\
\hline 17 & Sweden & 60 & Female & $\begin{array}{l}\text { Breast } \\
\text { cancer }\end{array}$ & Filgrastim & 11 days & Docetaxel & Thoracic & Steroid & $\begin{array}{l}\text { Resolved in } \\
10 \text { days }\end{array}$ & $(10)$ \\
\hline 18 & Japan & 65 & Female & $\begin{array}{c}\text { Liver } \\
\text { metastasis } \\
\text { of } \\
\text { pancreatic } \\
\text { cancer }\end{array}$ & Pegfilgrastim & 8 days & FOLFILINOX & Thoracic & None & $\begin{array}{l}\text { Resolved in } \\
10 \text { days }\end{array}$ & $\begin{array}{l}\text { Present } \\
\text { case }\end{array}$ \\
\hline 19 & Japan & 74 & Female & $\begin{array}{l}\text { Tongue } \\
\text { cancer }\end{array}$ & Pegfilgrastim & 8 days & $\begin{array}{l}\text { CDDP, 5-FU, } \\
\text { DOC, } \\
\text { Dexamethasone }\end{array}$ & Thoracic & None & $\begin{array}{l}\text { Resolved in } \\
10 \text { days }\end{array}$ & $\begin{array}{l}\text { Other case } \\
\text { in our } \\
\text { department }\end{array}$ \\
\hline 20 & Japan & 47 & Female & $\begin{array}{l}\text { Uterine } \\
\text { cancer }\end{array}$ & Pegfilgrastim & 10 days & $\begin{array}{c}\text { Carboplatin, } \\
\text { Paclitaxel }\end{array}$ & Thoracic & None & $\begin{array}{l}\text { Resolved in } \\
14 \text { days }\end{array}$ & $\begin{array}{l}\text { Other case } \\
\text { in our } \\
\text { department }\end{array}$ \\
\hline 21 & Japan & 43 & Female & $\begin{array}{l}\text { Uterine } \\
\text { cancer }\end{array}$ & Pegfilgrastim & 7 days & $\begin{array}{l}\text { Carboplatin, } \\
\text { Paclitaxel }\end{array}$ & Thoracic & None & $\begin{array}{l}\text { Resolved in } \\
21 \text { days }\end{array}$ & $\begin{array}{l}\text { Other case } \\
\text { in our } \\
\text { department }\end{array}$ \\
\hline
\end{tabular}

HL: hyperlipidemia, MI: myocardial infarction, US: United States, FOLFILINOX: fluorouracil, levofolinate calcium, irinotecan hydrochloride hydrate, and oxaliplatin, CDDP: cisplatin, 5-FU: 5-fluorouracil, DOC: docetaxel hydrate, G-CSF: granulocyte-colony-stimulating factor

active phase of Behçet's disease (14). Since G-CSF increases the number of neutrophils, it is reasonable to consider that the administration of G-CSF triggered a pathomechanism similar to that involved in vascular Behçet's disease.

However, one of the most important findings of this report was that most of the patients with aortitis induced by
G-CSF were Japanese women. These features are actually characteristic of TAK, in which neutrophil-associated diseases, such as pyoderma gangrenosum, have also been documented $(15,16)$. Therefore, the mechanisms underlying the aortitis induced by G-CSF use might also contribute to the initiation of TAK. The association of specific human leukocyte antigen (HLA) with TAK has been recognized (17). Al- 
though we did not perform HLA-typing of our patients, checking the HLA status might be useful for clarifying the mechanisms involved in G-CSF-induced aortitis. Umeda et al. reported a patient with GCA that developed after the administration of G-CSF (18). Because the patient was treated with prednisolone, it was difficult to distinguish G-CSFinduced arteritis from GCA in that case. However, their patient possessed HLA alleles, a condition that is reportedly frequent in GCA, suggesting an association of G-CSF with the initiation of LVV.

In conclusion, G-CSF-induced aortitis can show spontaneous resolution and thus does not necessarily require continuous immunosuppression. However, in rare cases, aortic dissection has been reported, which may support the use of short-term immunosuppression therapy. It should also be noted that repeated G-CSF use causes aortitis to recur in different locations, presenting as migratory aortitis.

Written informed consent for publication of this case report was obtained from the patient.

The authors state that they have no Conflict of Interest (COI).

\section{Financial Support}

This work was supported by JSPS KAKENHI Grant Numbers $16 \mathrm{H} 06642$ and $18 \mathrm{~K} 16136$ for TS and research grants from the Kanae Foundation and Nanbyo Medical Foundation for TS.

\section{Acknowledgement}

The authors thank the staff of the Department of Hematology \& Rheumatology, Tohoku University for their helpful discussions.

Tsuyoshi Shirai and Hiroka Komatsu contributed equally to this work.

\section{References}

1. Bossone E, Pluchinotta FR, Andreas M, et al. Aortitis. Vascul Pharmacol 80: 1-10, 2016.

2. Jennette JC, Falk RJ, Bacon PA, et al. 2012 revised International Chapel Hill Consensus Conference Nomenclature of Vasculitides. Arthritis Rheum 65: 1-11, 2013.

3. Keser G, Aksu K. Diagnosis and differential diagnosis of largevessel vasculitides. Rheumatol Int 39: 169-185, 2019.
4. Mutoh T, Ishii T, Shirai T, et al. Refractory Takayasu arteritis successfully treated with rituximab: case-based review. Rheumatol Int 39: 1989-1994, 2019.

5. Adiga GU, Elkadi D, Malik SK, Fitzpatrick JD, Madajewicz S. Abdominal aortitis after use of granulocyte colony-stimulating factor. Clin Drug Invest 29: 821-825, 2009.

6. Gasparyan AY, Ayvazyan L, Blackmore H, Kitas GD. Writing a narrative biomedical review: considerations for authors, peer reviewers, and editors. Rheumatol Int 31: 1409-1417, 2011.

7. Darie C, Boutalba S, Fichter P, et al. Aortitis after G-CSF injections. Rev Med Interne 25: 225-229, 2004 (in French, Abstract in English).

8. Lardieri A, McCulley L, Jones SC, Woronow D. Granulocyte colony-stimulating factors and aortitis: a rare adverse event. Am J Hematol 93: E333-E336, 2018.

9. Miller EB, Grosu R, Landau Z. Isolated abdominal aortitis following administration of granulocyte colony stimulating factor (GCSF). Clin Rheumatol 35: 1655-1657, 2016.

10. Parodis I, Dani L, Notarnicola A, et al. G-CSF-induced aortitis: Two cases and review of the literature. Autoimmun Rev 18: 615620, 2019.

11. Sato Y, Kaji S, Ueda H, Tomii K. Thoracic aortitis and aortic dissection following pegfilgrastim administration. Eur $\mathrm{J}$ CardioThorac 52: 993-994, 2017.

12. Mutoh T, Shirai T, Fujii H, Ishii T, Harigae $H$. Insufficient use of corticosteroids without immunosuppressants results in higher relapse in Takayasu arteritis. J Rheumatol 47: 255-263, 2020.

13. Spiekermann K, Roesler J, Emmendoerffer A, Elsner J, Welte K. Functional features of neutrophils induced by G-CSF and GMCSF treatment: differential effects and clinical implications. Leukemia 11: 466-478, 1997.

14. Kawakami T, Ohashi S, Kawa $Y$, et al. Elevated serum granulocyte colony-stimulating factor levels in patients with active phase of sweet syndrome and patients with active Behçet disease - implication in neutrophil apoptosis dysfunction. Arch Dermatol 140: 570574, 2004.

15. Shirai T, Hanaoka R, Goto $Y$, et al. Takayasu arteritis coexisting with sclerosing osteomyelitis. Intern Med 57: 1929-1934, 2018.

16. Ujiie H, Sawamura D, Yokota K, Nishie W, Shichinohe R, Shimizu H. Pyoderma gangrenosum associated with Takayasu's arteritis. Clin Exp Dermatol 29: 357-359, 2004.

17. Renauer P, Sawalha AH. The genetics of Takayasu arteritis. Presse Med 46: e179-e187, 2017.

18. Umeda M, Ikenaga J, Koga T, et al. Giant cell arteritis which developed after the administration of granulocyte-colony stimulating factor for cyclic neutropenia. Intern Med 55: 2291-2294, 2016.

The Internal Medicine is an Open Access journal distributed under the Creative Commons Attribution-NonCommercial-NoDerivatives 4.0 International License. To view the details of this license, please visit (https://creativecommons.org/licenses/ by-nc-nd/4.0/).

(C) 2020 The Japanese Society of Internal Medicine

Intern Med 59: 1559-1563, 2020 